Article

\title{
Resource and Information Access for SME Sustainability in the Era of IR 4.0: The Mediating and Moderating Roles of Innovation Capability and Management Commitment
}

 \\ and Irfan Hameed ${ }^{4}$ \\ 1 Department of Management, Faculty of Business Administration, Iqra University, \\ Karachi 75500, Sindh, Pakistan \\ 2 School of Quantitative Sciences, College of Art and Sciences, Universiti Utara, \\ Malaysia 06010, Kedah, Malaysia; salisu_isyaku@ahsgs.uum.edu.my \\ 3 Department of Management Sciences, The Islamia University of Bahawalpur, \\ Bahawalpur 63100, Punjab, Pakistan; hassan.danial@iub.edu.pk (H.D.A.); jawad.iqbal@iub.edu.pk (J.I.) \\ 4 Department of Marketing, Faculty of Business Administration, Iqra University, \\ Karachi 75500, Sindh, Pakistan; irfan.h@iqra.edu.pk \\ * Correspondence: muhammadimran@oyagsb.uum.edu.my or imran@iqra.edu.pk; Tel.: +92-333-356-8445 \\ or $+60-111-110-1574$
}

Received: 12 March 2019; Accepted: 8 April 2019; Published: 12 April 2019

\begin{abstract}
In the era of industrial revolution 4.0 (IR 4.0), sustainability has been a serious challenge of contemporary small and medium enterprises (SMEs). Using Natural Resource-Based-View (NRBV), the current paper examines the moderated mediation model of the role of information access in the sustainability of SMEs, through the mediating role of access to resource and innovation capability in the relationship between information access and sustainability, and the moderating role of management commitment in the relationship between innovation capability and SME sustainability. This paper gathered data from 222 SMEs in Pakistan. The study used a purposive sampling technique to distribute the survey questionnaire. Smart-PLS software was used to analyze the data. The study finding indicates that access to information affects both sustainability and innovation capability. Moreover, access to resources affects innovation capability, though it did not affect SME sustainability. Furthermore, innovation capability mediates the relationship between access to resources, access to information, and SME sustainability. Additionally, management commitment moderates the relationship between access to information and innovation capability; however, it does not moderate the relationship between access to resources and innovation capability. Practical, theoretical, and methodological implications are discussed in the study.
\end{abstract}

Keywords: industrial revolution (IR 4.0); sustainability; innovation capability; information; resource; management commitment; SMEs

\section{Introduction}

Small and medium enterprises (SMEs) play a major economic role as they represent around 90 percent of organizations and in excess of 70 percent of jobs globally, as indicated by the Organization for Economic Co-Operation and Development [1]. Along these lines, they have become an essential wellspring of economic development [2]. The need to enhance the overall sustainability of SMEs is vital [3]. Be that as it may, SMEs are regularly defenseless and not sufficiently powerful to withstand the surges of economic and worldwide competitive challenges [4,5]. It has been reported that $70 \%$ 
or more of SMEs lack sustainability, and as such they often do not survive beyond five years [6]. This has also been the trend for SMEs in Pakistan, where they are officially ignored [7]. SME activities enhance social cohesion by allowing individuals to start their own business, irrespective of their socio-economic or personal characteristics. However, the existence of a large number of SMEs does not guarantee such positive effects: once a new business is formed, it must endure and grow to become a dynamic SME capable of reducing unemployment and fostering innovation. Yet, business activities are sometimes detrimental to the host community and, as such, SMEs begin to realize that their roles and responsibilities should not be restricted to only their immediate owners but to all stakeholders, including the host community and society at large. Previous literature has indicated that sustainability is a crucial issue in SMEs and, therefore, the analysis of those elements possibly enhancing sustainability becomes a pertinent issue.

Generally, it is recognized that the idea of sustainable development influences all business undertakings [8]. Both large organizations and SMEs are influenced by all-inclusive sustainability issues; for example, rising energy costs, growing worries about the wellbeing and security of workers, and carbon emissions. At the same time, organizations of all sizes are being confronted to assume responsibility for their business operations and the related effects on nature and society [9]. This responsibility can be communicated as adherence to laws and regulations, mandatory reactions to public pressures, and proactive activities and strategies of the organization [10]. Businesses that fail to adhere to this will experience unexpected outcomes. As such, sustainability has become gradually essential for SMEs as they face strong competition from larger companies and scrutiny from different stakeholders [6,11]. The concept of sustainability in the context of SMEs has become a foundation to help understand the life of many firms in the current competitive arena. Yet, the majority of SMEs have low levels/degrees of understanding of sustainable practices [12]. Additionally, the issue of sustainability in the context of SMEs has received little attention in the literature, as most academic research on sustainability has focused on examining the phenomenon in big companies [13-15].

The advent of new technologies, new production methods, new decision-making tools, and the dynamic and high customer demand of the IR 4.0 has compelled organizations to change their operational strategies. The IR 4.0 has brought about a larger volume, variety, and speed of factory-produced goods [16]. Unfortunately, SMEs have been left far behind, because they generally lack basic resources and information. To endure, SMEs must screen their organizations and utilize the majority of their resources and information proficiently [17]. Access to resources and information is a major challenge, cited by the GEM 2012 as one of the problems working against SME sustainability [1]. According to the World Bank [18], the biggest impediment to SMEs is the limited access to resources, especially financial resources. Further, the United Nations (UN) has professed a shortage of access to information to be the major challenge facing SMEs in developing countries [19]. Additionally, previous studies in developing countries have shown that many SME owners are unable to access the resources and information necessary for the expansion of their business, and consequently the majority of them die prematurely, often within five years of start-up [20]. Yet, according to the resource dependency view [21], positive entrepreneurial outcomes depend on the availability of resources such as human knowledge, information, materials, and finance [22]. Further, entrepreneurship theory recommends that an adequate information spectrum will allow entrepreneurs to perceive market demands, and foresee potential opportunities [23,24].

A venture's successful emergence, survival, and growth depend on meeting resource and information requirements [25], therefore different scholars have associated access to resources and information with various outcomes such as entrepreneurial intention [26], new venture start-up [27], entrepreneurial opportunities exploitation [28-30], and psychological empowerment [31]. However, very few studies have explained the effects of such outcomes on sustainability practices. Additionally, although some studies are related to these constructs, what is conspicuous is that they tend to ignore the fact that not having access to resources and information alone does not explain the sustainability and other outcomes of an entrepreneurial venture. In other words, what are the underlying mechanisms 
that explain why access to resources predicts an SMEs sustainability? Additionally, there have been mixed findings on how resources and information access influence firm innovation capability, and as such the current study introduces management commitment to serve as a moderating variable between access to resources and information, and a firm's innovation capability.

The acquisition and expansion of innovation capability is a serious test for the sustainability, growth and survival of SMEs, as they usually suffer from a shortage of resources and information, and show inadequate attentiveness to environmental happenings. Although there is a plethora of research on innovation capability, studies concentrating on the innovation capability of SMEs are scarce when compared to research focusing on large organizations [32], and their findings concerning antecedents and consequences of innovation capability are generally fickle and inconsistent [33]. Additionally, the limited studies on the innovation capability of SMEs have fixated largely on two main areas: firm performance [33,34] and internal and external factors [26,35]. Furthermore, prior empirical research has not sufficiently explored the influence of other capabilities (resources and information) on innovation capability and SME sustainability. Moreover, studies which concentrate on the elements influencing SME innovation capability in terms of barriers, facilitators, and moderators are sparse [36].

This current study advocates that, although SMEs might have little direct control over the environment within which they operate, they do have options vis-à-vis how they construe and react to it. The higher their access to needed resources and information, the higher the commitment of the management, and the greater their capability to innovate, the more prepared they will be to overcome hitches and to take charge of circumstances in order to conduct themselves in a more responsible manner, such as through protecting their operational environments. Theoretically, although there are studies that relate the variable of the current study in a different fashion, however, there are limited studies regarding the mediating role of innovation capability and the moderating effect of management commitment on the relationship between information accessibility and resource availability and SME sustainability. Consequently, this current research examines how information accessibility and resource availability affect the sustainability of SMEs through the mediation and moderating role of innovation capability and management commitment, respectively.

In the following section, this study concisely examines the relevant literature on SME comportment and sustainability practices, and presents the premise that innovation capability and management commitment have explanatory worth for behavior choices. This is followed by a comprehensive discussion of the methodology and approaches used to collect data. Finally, the study explains why some SMEs adopt sustainability practices while others do not, even when operating within the same contexts and, often, sharing analogous concerns. This study is based on an analysis of data collected from the SMEs in Pakistan.

\section{Literature Review}

One of the common subjects of the literature on SMEs is the test they face when looking to behave sustainably $[37,38]$. Certainly, examination of the research on small businesses has for quite a while required an orientation towards studies which not only concentrate on their distinctiveness, but also address key inquiries identifying the selection of sustainability practices by a few SMEs, however not others [15].

There are many constraints that impact an SME's ability to respond positively to environmental challenges and which may transform their likely positive attitudes to action, including a lack of required information and a general lack of resources and capability for innovation. Be that as it may, research has up to this point neglected to yield convincing results on how the access to resources, information, and other capabilities can impact the pro-sustainability practices of SMEs [8].

Although SMEs evidently have lesser accumulations of slack resources when compared to large organizations, they might have promising organizational capabilities empowering them to proactively address environmental concerns [10]. 
Resources are material and non-material capabilities that facilitate and support production and productivity. Kanter [39] classified resources into three wide categories: (1) information; (2) motivational resources; and (3) material resources. This classification appears to cover most of the important kinds of resources needed by any organization. Access to information is normally viewed as crucial for SMEs. For instance, Cooper et al. [40] contend that the procedure of venture formation may be regarded as a "process of learning, of overcoming the liabilities of newness through information acquisition". In this study, we use access to information to predict access to other resources.

\section{1. "Natural" Resource-Based View of the Firm ("N"RBV)}

The resource-based view of the firm (RBV) supposes that resources, 'stocks of available factors that are owned or controlled by the firm', or capabilities, 'a firm's capacity to deploy resources' [41], are both heterogeneously circulated among organizations and imperfectly mobile. These allow not only for the existence of variances in firm resources at their disposal, but also for these variances to continue over time [42]. Based on these conventions, RBV researchers assume that, if a business owns and exploits their endowed resources as well as capabilities that are valuable and rare, it will accomplish a competitive advantage, and if these endowed resources and capabilities are as well both inimitable and non-substitutable, the business will sustain this advantage, and further the realization of such advantages will permit the business to achieve good performance both short-term and long-term [41-45].

Prior research has regularly addressed sustainability implementation from the RBV standpoint [46-52]. The RBV maintains that organizations achieve competitive advantages through the application of valuable resources at hand. To grasp these competitive advantages, the resources should be valuable, rare, inimitable, and non-substitutable [44]. According to the RBV, sustainability practices could be part of organizational capabilities that add to changeability in performance across organizations [42-44]. According to this theory, one fundamental motive for why larger corporations might be more able to implement sustainability is their greater availability of information and resources regarding sustainability management tools, and the ability to unravel the impending advantages associated with them [53-56]. Golicic and Smith [57] argued that the RBV is the most frequently used theory in studies which concentrate on environmentally sustainable practices. Hart [58] disputed that this method was sufficient, and that a competitive advantage could come from an organization's environmentally responsible capabilities. He therefore stretched the assumptions of the RBV to incorporate the natural environment. He termed this the "natural resource-based view" (NRBV). Hart and Dowell [59] evaluated the relevant studies that built upon the NRBV and the strategic capabilities pronounced in Hart's [58] opinion: product stewardship, pollution prevention, and clean technology. They found those capabilities to be meticulously related to the environmental and social facets of sustainability, while RBV postulated that an organization's impending competitive advantage depends on its available resources that are valuable and rare, but not imitable. NRBV enlarges the domain of this theory to incorporate the organization's environmental practices, and has been embraced by several prior studies that relate improved environmental practices to enhanced economic and environmental performance $[47,60-63]$.

\subsection{Sustainability}

SMEs recognize that they operate in a broader intricate adaptive system(s), hence they begin to understand their roles and responsibilities to not only their immediate owners, but to society at large. As such, sustainability has become a major concern for SMEs that integrate environmental as well as social matters into their strategy $[64,65]$. Sustainability is an alternative approach to managing the organization differently from the traditional, profit-oriented approaches, which holistically takes economic, social, and environmental issues into consideration [66]. It encompasses the firm's outcomes from its activities, and denotes the level at which the firm is capable of keeping its business actions achievable and practical in the long run [67]. According to Labuschagne and Brent [68] business 
sustainability refers to "adopting business strategies and activities that meet the needs of the enterprise and its stakeholders today, while protecting, sustaining and enhancing the human and natural resources that will be needed in the future". In other words, it is the execution of business actions that aim to meet the existing needs of the organization and its members, and at the same time sustains the resources (human and natural) that will be employed in the future [68]. The "sustainability revolution" symbolizes a greater emphasis on long-term effects [69]. According to Beddoe et al. [70], accomplishing sustainability is a complex phenomenon for all parties, including organizations and people alike, and hence it requires a series of empirical investigations. This study extends the boundary of knowledge on sustainability and empirically studies the extent to which access to resources, information, and innovation capability leads to sustainability within SMEs.

\subsection{Access to Resources}

Resource acquisition is referred to as the process by which organizations access their resources, from both internal and external environments. According to Kanter [39], "access to organizational resources means more general managers working through smaller business units; more project teams that have budgets; special resource pools of unallocated funds that people can tap to solve problems. In short, they make it easier for people to tap locally what they need to get things done". Types of resources include funds, space, material, and time. A deficiency of access to the needed organizational resources leads to helplessness and dependency [71]. Access to resources augments the firm's sense of self-efficacy and mechanism for control over environmental eventualities [72,73].

Access to resources has proved to be critical in the entrepreneurial process [74]. The sustainability of any SME is argued to be affected by various factors, among which is the access to resources [75-77]. Consequently, a lot of scholars have devoted much of their attention to explaining the critical impact resources have on SME sustainability $[27,78,79]$. According to resource-advantage theory, resources are "tangible and intangible entities available to the firm that enable it to produce efficiently and effectively" [80].

Hypothesis 1 (H1). Access to resource is positively related to SME sustainability.

\subsection{Access to Information}

Information is an economic resource, and lack of it has gradually been acknowledged in the literature as one of the major causes of many negative outcomes [81]. To be successful, firms are required to develop exceptional insights, or to hold special information allowing them to discover and explore opportunities [82]. Information is sterilized, formatted, and organized facts that are useful, meaningful, and best describe situations and conditions [83-85]. It is "knowledge that leads to immediate progress on a current assignment or project" [86]. The concept has received great attention in the literature, as organizations need inputs from their environment-both internal and external-to minimize uncertainties [87]. Therefore, many studies have been undertaken that have clearly established the importance of information [88]. For instance, Stam et al. [89] and Autio et al. [90] argued that information shapes organizational evaluation of opportunities, and spurs organizational actions which consequently lead to positive outcomes. Moreover, information serves as a regulatory mechanism, increases satisfaction, reduces ambiguity by clarifying procedures, priorities, and decisions [91], and boosts innovativeness and competitiveness [92]. Therefore, lack of adequate information can negatively affect positive outcomes for SMEs, such as sustainability and performance [28,93].

Information accessibility is an essential asset that aids entrepreneurial action and enhances organizational outcomes [94]. Furthermore, information access makes firms rational in their decision-making process, and helps provide opportunities for identification and exploitation [34]. For example, Cooper, Folta and Woo [40] contended that the procedure of venture formation may "be viewed as a process of learning, of overcoming the liabilities of newness through information acquisition". 
Although, information has proved to be a critical asset in the life of an entrepreneurial firm [95], according to Kirzner [96] information is not concentrated equally but is asymmetrically distributed, hence some firms have varied access to the required information, while others are information deficient [40]. As a result, their level of opportunity recognition, evaluation, and exploitation differs, along with their decision-making ability [97]. Even though access to information has been extensively studied, there is the need to find out more regarding its effects on different entrepreneurial outcomes [93]. Additionally, more rigorous and in-depth empirical investigation [86] that examines access to information accuracy is required and recommended.

Hypothesis 2 (H2). Access to information is positively related to SME sustainability.

\subsection{Information Accessibility and Resource Availability}

The access to information and other critical resources is of key importance for SME sustainability [69]. Venture creation is a prodigious process through which entrepreneurs exploit opportunities by getting important information and resources [22]. Entrepreneurial information, for example new learning, market intelligence, and novel ideas, impacts an entrepreneur's capacity to perceive opportunities [68]. In addition, resource accessibility influences an entrepreneur's key capacity to find open doors for income generation [28]. SMEs whose access to information is either inadequate or very expensive may be uninformed of other resources accessible to them, and they may fail to apportion their resources proficiently, may waive income-enhancing prospects, or may accept an unreasonably high degree of risk.

This would be the situation if, for instance, they did not know the necessities for acquiring credit with ideal conditions, they did not know about current markets for their products and services, or if they were ignorant about accessible technologies that could expand their income. In the particular setting of financial markets, deficient access to information can lead to picking imperfect credit, investment funds, or insurance strategy in spite of the alternatives accessible to them, or to just swear off taking part in formal financial markets altogether [98]. As such, timely access to valuable information is necessary for making sound decisions, particularly in the era of IR 4.0, in which information is one of the essential assets that can guarantee positive outcomes by creating access to needed resources. Therefore, this study hypothesized:

Hypothesis 3 (H3). Access to information leads to resource accessibility.

Although there are enough pieces of evidence showing that access to information leads to SME sustainability, this study, in addition to confirming this relationship, used access to resources as a mediator between access to information and SME sustainability. Access to resources was used in previous studies as an intervening variable $[34,99]$. In the current study it is assumed that having access to information leads to having access to important resources, and together this affects SME sustainability. Therefore, the following hypothesis is proposed:

Hypothesis 4 (H4). Access to information mediates the relationship between access to resources and SME sustainability.

\subsection{Innovation Capability}

In swiftly varying business environments, innovation is a crucial asset for firms' sustainability, growth, and survival [100]. The development of industry under the 4.0 revolution is subject to fierce competition and changes in consumer needs, and organizations have been heavily dependent on innovation to reinforce core capabilities and build competitive advantages in this environment. For the last two decades, economic systems have changed rapidly into knowledge and creative economies. Innovation has become a key element, irrespective of company size and type. After becoming attached 
to limited resources and scant information and competencies, SMEs saw the necessity of advancing competitiveness by effective and efficient innovation [94].

Innovation capability is described as the universal, corporate-wide prospective of an organization to breed new and inimitable values. It relates to a range of areas, and is affected by different factors inside and outside of the organization [101]. Innovation is a main influencer of important cost-effective outcomes, such as sustainability, production profitability, and growth [72,102]. Hence, organizations are supposed to improve their innovation capability to develop novel outcomes, be inventive in procedures, breed new ideas, develop techniques, and take risks. Businesses with a high level of innovation capability are more likely to achieve better positive outcomes, guided by technological advancement and malleable reactions in changing environments. Innovation capability stimulates innovations and accomplishes an extraordinary innovation productivity that contributes to a firm's positive outcomes [34,103].

SMEs are expected to be equipped to react positively to variations brought by the market, and moreover by their aptitude to distinguish themselves from their challengers or their competence to be inventive in order to stay alive in business. Undeniably, SMEs need to innovate in order to survive and create competitive advantages [101]. The necessity for SMEs to innovate has motivated changes at various levels. Firstly, globalization has exposed SMEs to greater competitiveness. Secondly, SMEs cannot concentrate solely on position markets any longer. Thirdly, technological developments have occasioned the quick advancement of innovation, knowledge and information, placing SMEs into a more competitive environment. Lastly, the demands of consumers are now concentrated on greater quality products and services [104].

A vast amount of human and monetary resources and information are a prerequisite for driving innovation. Information and resources are important to pursuing innovation, and hence deficiency in the required information and resources to sustain innovation increases the likelihood of disappointment, resulting in a lack of SME sustainability. Although Halme and Korpela [105] argued that innovations can be made with blends of diverse resources and information, and Petruzzelli et al. [106] showed that the innovation capability of an organization depends on the resources they employ, Hadjimanolis [107] revealed that SMEs are more likely to be confronted with more obstacles to innovation than bigger organizations, due to insufficient access to information and resources. Galia and Legros [108] showed that resources and information inadequacy are some of the main obstacles to innovation experienced by many SMEs. Further, Madrid-Guijarro et al. [109] revealed that a lack of financial resources and information impacts the degree of innovation of SMEs negatively. Additionally, Elmquist and Le Masson [110] highlighted how intangible resources, particularly monetary support, are imperative for constructing the innovation capability of organizations. Hence, the current literature does agree that SMEs are faced with substantial problems in nurturing innovation, as a result of a lack of both resources and information, and these are likely to become obstacles to innovation [36].

A company's innovation capability is meticulously connected to its aptitude to access and employ its resources and information. Some of the elements inducing innovation capability in organizations are access to resources and information. Preceding investigations indicate a positive relationship between access to resources, access to information, and innovation capability. Organizations have diverse means of accessing resources and information, and this has effects on their innovation undertakings. Such resources and information can come from investment processes amassing within organizations, or can be provided by external representatives through strategic alliances or contracts $[111,112]$. This study therefore posits:

Hypothesis 5 (H5). Access to resources affects SME innovation capability.

Hypothesis 6 (H6). Access to information affects SME innovation capability.

\subsection{Innovation Capability and SME Sustainability}

One gradual, vital way for SMEs to compete in contemporary, ever-changing environments while contributing to sustainable development are sustainability-driven innovation practices $[113,114]$. Sustainability is a main driver of business change [115-117]. In a world of limited resources, 
its implications for innovation are unequivocal; hence, the field of innovation and sustainability (the prospects to innovate for sustainability) has gathered a growing amount of attention among researchers and practitioners. It points to the "importance of firms to create, redesign, adapt, and diffuse environmentally sound technologies" [118]. Brem and Ivens [119] maintain that several firms offer convincing proof that innovation and sustainability are meticulously related. According to Ardito et al. [120], achieving simultaneous economic environmental benefits is one of the innovation plans of the modern day organization.

Innovation capabilities are regarded as crucial constituents for any organization, regardless of their size and form, for sustainable transformations in unsettled business environments [121]. As such, it has been generally recognized that innovation is crucial for attaining sustainability [122]. Several studies show that, to achieve sustainability, the efficiency of the existing use of resources must rise by a factor of about 10 to 50. Such efficiency leaps require radical new solutions and attest to the central role of innovations in sustainability. Similarly, there is a general consensus that the challenges of sustainability present substantial potential for innovation and novel business opportunities. Sustainability is an opportunity, a pathway to innovation and creative thinking, and an investment in the future [123]. Consequently, the connections between a firm's innovation capability and sustainability play an imperative role for firms to establish their competitive edge [124]. Therefore, this study hypothesized:

\section{Hypothesis 7 (H7). Innovation capability affects SME sustainability.}

\subsection{Innovation Capability as a Mediator}

Although resources and information are valuable for sustainability, they are exponentially more valuable when combined with the appropriate capability [125], and this current study argued that having access to both resources and information needs to be complemented with the appropriate innovation capabilities. According to the RBV, organizations will have a combination of diverse resources and varying degrees of capability. Organizational survival and sustainability are contingent upon the organizational capability to generate novel assets, build upon the current competencies, and make current capabilities more inimitable [43]. Furthermore, what is generally known in the literature is that access to resources and information affect a variety of outcomes [99], but how and why has been left unexplored, and is therefore uncertain. Thus, the literature has not fully provided clear reasons as to why and how access to resources and information affects entrepreneurial outcomes. Hence, this study proposes that:

Hypothesis 8 (H8). Innovation capability mediates the relationship of access to resources and SME sustainability.

Hypothesis 9 (H9). Innovation capability mediates the relationship of access to information and SME sustainability.

\subsection{Management Commitment}

Top management assumes a fundamental role in actualizing organizational plans, and as such their decisions encompass resource commitments and firm changes [126]. A critical review of the literature suggests that when top management is focused on innovation capability, this is bound to help in actualizing organizational innovation practices. For example, top management may focus on limiting innovation problems emerging in operations, examine the impact of these capabilities on the firm's activities, recognize innovation capability as a way of building and sustaining a competitive edge, increase the attention towards competitors' innovation capability methodologies, and evaluate industry innovation requirements and report innovation techniques, plans, and activities to all stakeholders. This study contends that the degree to which top management is committed corresponds to the positive link between access to resources, access to information, and innovation capability. Accordingly, top 
management commitment is expected to moderate the relationship between access to resources, access to information, and innovation capability.

Management commitment plays an indispensable role in building capabilities, resource allocation, and helping the firm to gain a competitive advantage [127]. Jayaram et al. [128] highlight that innovation outcomes depend on the particular action strategies that the firm practices to upsurge its innovative capability. Explicitly, in the management and strategy literature, they found that changes in management commitment to innovation affect a firm's innovation outcomes. Kuratko et al. [129] cite a lack of top management commitment to innovation as a common reason for business failure.

The effect of management commitment on firm-level initiatives has been extensively investigated [130,131]. Researchers have contended that management commitment affects organizational outcomes [132,133], yet the evidence for this is inadequate. Hence, in the current study, management commitment is used as a moderating variable on the relationship between access to resources and information and SME innovative capability. The construct was also used in previous literature as a moderating variable $[130,134]$. It is argued here that the relationship is strengthened when management is highly committed.

Hypothesis 10 (H10). Management commitment moderates the relationship between access to information and SME sustainability, such that the relationship is stronger when management commitment is high.

Hypothesis 11 (H11). Management commitment moderates the relationship between access to resources and SME sustainability, such that the relationship is stronger when management commitment is high.

After the detail discussion of the past published literature the current study presents the research framework, in which can see the study endogenous and exogenous constructs with hypothesis direction. The study' research framework can see in Figure 1.

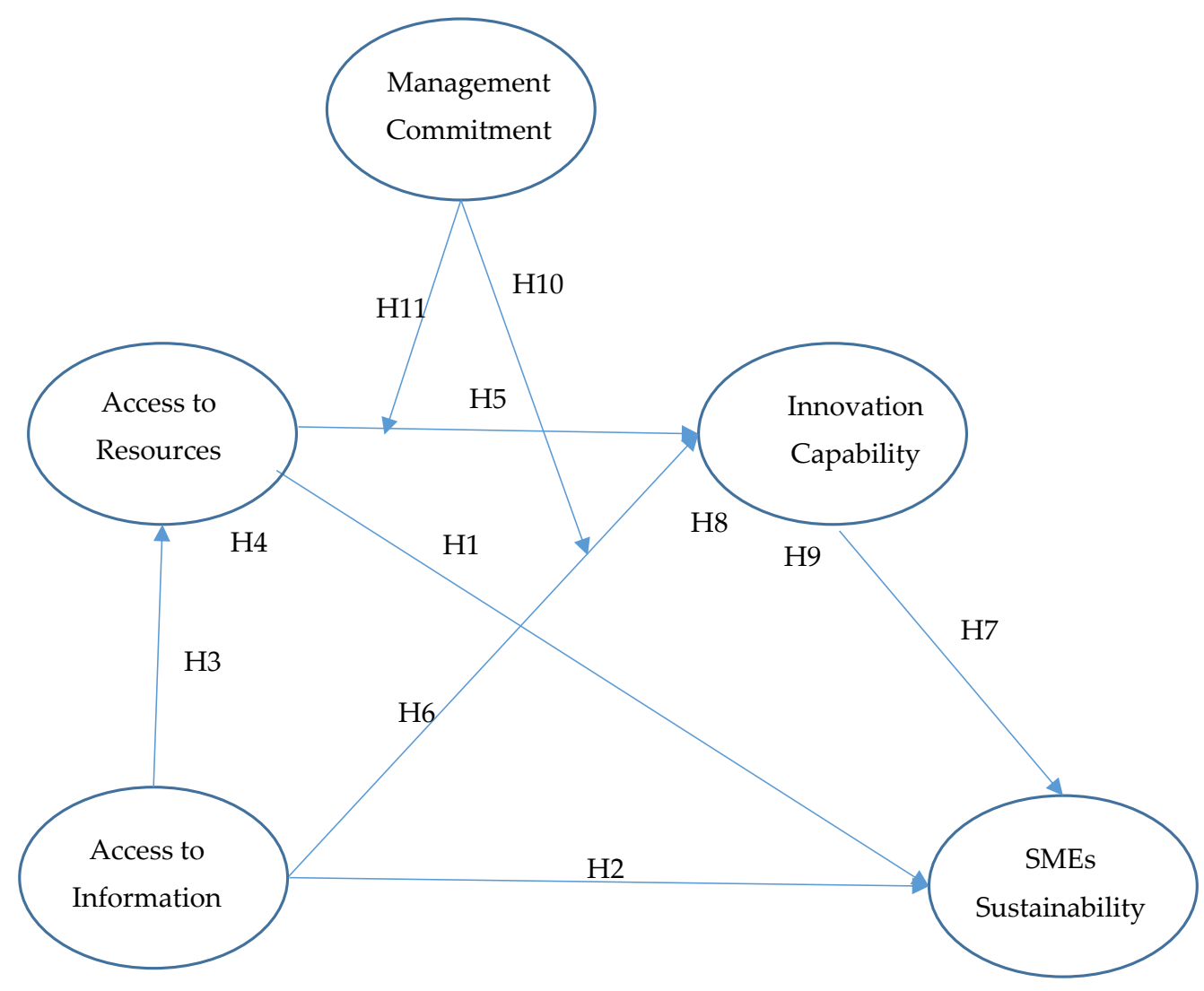

Figure 1. Hypothesized model. 


\section{Research Methodology}

The participants included resilient SMEs who have been in business for more than five years. To decrease the impact of common method bias (CMV), an introductory letter was appended guaranteeing the respondents that their interest in the research was willful and unidentified [135]. Following the questionnaires being completed, a few questionnaires were removed due to incomplete responses.

In terms of the study sample size, Chin [136] stated that 100 to 200 respondents are adequate for partial least square structural equation modeling (PLS_SEM) analysis. As the current study was unable to obtain the full sampling frame of the population, $G^{*}$ power was used to decide the sample size of the study $[137,138]$. Furthermore, Cohen [139] suggested the minimum values of statistical power should be $80 \%$ and the effect size (f2) should be 0.15 , with one predictor. However, in this study, G*Power showed the minimum sample size was 92 respondents with predictors. In other words, the absolute sample estimate required was 92 . At first, 358 questionnaires were distributed utilizing the purposive sampling strategy, yet just 222 satisfied the criteria, and were consequently utilized for the main study [136]. Subsequently, the usable sample size was 222, including 166 males and 56 females. A total of 168 were married, while 54 were single. Further, the average age of the respondents was 37, with $75 \%$ having obtained a bachelor's degree or higher qualification.

For the analysis of the data, PLS-SEM (Smart-PLS) is used due to its suitability in handling complex models, and having more statistical power than most of the statistical tools available [140]. The current study.

\section{Measures}

All the propositions of our model were tested with multiple-items, as shown in Appendix 1. All the measures were extracted from current studies. Modification was undertaken on some items, so as to suit the context of the study. The items were measured using different scales. This is in an effort to minimize the consequences of common method bias. For instance, the exogenous variables were measured by a 5-point Likert-type scale, while the endogenous variables were anchored by a 7-point Likert-type scale.

Prior to the main study, the study followed the procedure outlined by Mishra et al. [141] and Hair et al. [142] to develop the instrument. Five SME experts were given a set of all the items of the constructs of this study. They were then requested to rate the extent to which they perceived these items to accurately measure their respective constructs on a 3-point Likert scale: " 3 = great extent, $2=$ somewhat, $1=$ not at all". Any items not marked "one" by any of the experts and marked "three" by at least three experts were included in the survey instrument. Additionally, the study conducted a pilot study with 30 SMEs to assess the reliability of the instruments. The Cronbach's Alpha of all the constructs were all greater than the 0.7 threshold. Consequently, no single item was deleted, and the final questionnaire consisted of 22 items. The following instruments were adopted from the previous literature to measure the variables of this study:

Sustainability: this study uses a five-item scale (Q29-Q33) from the Sustainability Practices Indicator to measure sustainability [143]. This was validated by Karkoulian et al. [144] and El Haddad et al. [145], and reported to have good psychometric properties. The five items measure the overall focus of the organization on sustainability practices and principles. These items were measured using a 7-point Likert-type scale ( $1=$ strongly disagree to $7=$ strongly agree). Access to information: four items were used to measure access to information, adopted from Spreitzer [31] and Yuan et al. [146]. Access to resources: three items were adopted to measure access to resources, from Spreitzer [31]. Innovation capability: was measured using six items from Bullinger, Bannert and Brunswicker [101] and Calantone et al. [147]; its reliability was reported in Kim, Park and Paik [36], and it was anchored using a 7-point Likert-scale from 1 (not at all) to 7 (extremely so). Management commitment: Klein, et al. [148] developed a scaled called the Unidimensional Target-Free (KUT), based on the 
conceptualization of Klein et al. [149]. A 7-point Likert-scale was also used, from 1 (not at all) to 7 (extremely).

\section{Research Findings}

Prior to the assessment of the model, this study performed primary data tests to make sure the data followed the multivariate assumptions. Since the data in this study were collected from a single source (SMEs), we used two statistical remedies to address the effect of common method variance (CMV). First, we used the Harman's one-factor test [135]. No single factor explains more than $50 \%$ of the cumulative variance. Using a more conventional method [150], the Full Collinearity with Warp-PLS software, the highest variance inflation factors (VIFs) among all the constructs was 2.41, which is not greater than the 3.3 threshold [150]. Therefore, CMV is not likely to be a serious worry in this study. To confirm the normality of the data, the study followed Hair et al. [151] by computing Mardia's multivariate skewness and kurtosis. According to the results, the data has multivariate normality concerns, and as such, a non-parametric software (Smart-PLS) was used for analysis. Further, this study computed the descriptive statistics of the latent variables' (LV) using their means and standard deviation. The result of this study shows that the highest mean was 4.131, and the lowest mean was 2.433.

\subsection{Measurement Model}

Prior to the testing of the hypothesized relationships, the study checked the model to ensure it possessed the mandatory reliability and validity. First, we determined the individual item reliability by item loadings, while the internal consistency reliability was determined by composite reliability (CR). As seen in Table 1, the loadings were all beyond the standard value of 0.5 [142], and the CR ranged between $0.811-0.909$. Therefore, these values exceed the 0.70 threshold. Second, the convergent validity was assessed by examining the loadings, $C R$, and average variance extracted (AVE). As seen in Table 1, the AVE values are $>0.5$ [140].

Table 1. Convergent validity.

\begin{tabular}{|c|c|c|c|c|}
\hline Constructs & Items & Loadings & $\begin{array}{c}\text { Composite } \\
\text { Reliability (CA) }\end{array}$ & $\begin{array}{l}\text { Average Variance } \\
\text { Extracted (AVE) }\end{array}$ \\
\hline \multirow[t]{5}{*}{ SME sustainability } & FS1 & 0.775 & \multirow[t]{5}{*}{0.886} & \multirow[t]{5}{*}{0.609} \\
\hline & FS2 & 0.793 & & \\
\hline & FS3 & 0.775 & & \\
\hline & FS4 & 0.795 & & \\
\hline & FS5 & 0.763 & & \\
\hline \multirow[t]{6}{*}{ Innovation Capability } & IC14 & 0.838 & \multirow[t]{6}{*}{0.909} & \multirow[t]{6}{*}{0.625} \\
\hline & IC15 & 0.772 & & \\
\hline & IC17 & 0.835 & & \\
\hline & IC18 & 0.742 & & \\
\hline & IC6 & 0.766 & & \\
\hline & IC8 & 0.785 & & \\
\hline \multirow[t]{3}{*}{ Access to Information } & INF1 & 0.684 & \multirow[t]{3}{*}{0.818} & \multirow[t]{3}{*}{0.601} \\
\hline & INF2 & 0.853 & & \\
\hline & INF3 & 0.779 & & \\
\hline \multirow[t]{3}{*}{ Access to Resources } & RES1 & 0.787 & \multirow[t]{3}{*}{0.885} & \multirow[t]{3}{*}{0.720} \\
\hline & RES2 & 0.888 & & \\
\hline & RES3 & 0.867 & & \\
\hline \multirow[t]{4}{*}{ Management Commitment } & MC1 & 0.887 & \multirow[t]{4}{*}{0.811} & \multirow[t]{4}{*}{0.529} \\
\hline & MC2 & 0.840 & & \\
\hline & MC3 & 0.559 & & \\
\hline & MC4 & 0.557 & & \\
\hline
\end{tabular}

The discriminant validity was determined using the Fornell \& Larcker criteria and Heterotrait-Monotrait (HTMT) ratio. For the Fornell \& Larcker criteria, from the Table 2, it can 
be seen that the square root of AVE is calculated and written in highlighted on the diagonal of the table. The latter, on the other hand, from Table 3, is based on the two thresholds of $<0.90$ [152] and $<0.85$ [153]. When both thresholds are considered, none of the values in the table are greater or equal to any of the two thresholds, signifying acceptable discriminant validity.

Table 2. Discriminant validity assessment using Fornell \& Larcker criteria.

\begin{tabular}{llccccc}
\hline \multicolumn{1}{c}{ Constructs } & $\mathbf{1}$ & $\mathbf{2}$ & $\mathbf{3}$ & $\mathbf{4}$ & $\mathbf{5}$ \\
\hline 1 & Access to Information & 0.775 & & & & \\
2 & Access to Resources & 0.438 & 0.848 & & & \\
3 & SME Sustainability & 0.474 & 0.255 & 0.780 & & \\
4 & Innovation Capability & 0.373 & 0.481 & 0.435 & 0.790 & \\
5 & Management Commitment & 0.030 & -0.008 & -0.091 & -0.096 & 0.727 \\
\hline
\end{tabular}

Table 3. Discriminant validity assessment using Heterotrait-Monotrait (HTMT).

\begin{tabular}{llccccc}
\hline \multicolumn{1}{c}{ Constructs } & $\mathbf{1}$ & $\mathbf{2}$ & $\mathbf{3}$ & $\mathbf{4}$ & $\mathbf{5}$ \\
\hline 1 & Access to Information & & & & & \\
2 & Access to Resources & 0.595 & & & & \\
3 & SME Sustainability & 0.618 & 0.299 & & & \\
4 & Innovation Capability & 0.483 & 0.561 & 0.493 & & \\
5 & Management Commitment & 0.062 & 0.058 & 0.100 & 0.091 & \\
\hline
\end{tabular}

\subsection{Testing of Hypotheses}

As depicted in Table 4 and Figure 2 the study assessed, first, the direct effect of access to information on an SME's sustainability and innovation capability. These relationships were significant $(\beta=0.382$, $t=6.457, p=0.000$ and $C I=0.256,0.461)$ and $(\beta=0.205, t=2.373, p=0.009$ and $C I=0.083,0.369)$, hence $\mathrm{H} 2$ and $\mathrm{H} 6$ were supported. Second, the study assessed the direct effect of access to resources on SME sustainability and innovation capability, and the former relationship was not significant ( $\beta=-0.068, t=0.992, p=0.161$ and $C I=-0.175,0.048)$, while the latter was significant $(\beta=0.390$, $t=5.326, p=0.000$ and $\mathrm{CI}=0.245,0.495)$, hence $\mathrm{H} 1$ was not supported but $\mathrm{H} 5$ was supported. Third, the study assessed the direct effect of access to information on access to resources $(\beta=0.438$, $t=6.393, p=0.000$ and $\mathrm{CI}=0.318,0.539$ ) and hence, $\mathrm{H} 3$ was supported. Fourth, the study assessed the direct effect of innovation capability on SME sustainability. The results $(\beta=0.325, t=5.068$, $p=0.000$ and $C I=0.200,0.416$ ) show the support of H7. Fifth, three mediation hypotheses were assessed; access to resources as a mediator of the relationship between access to information and SME sustainability, innovation capability as a mediator of the relationship between access to resources and SME sustainability, and innovation capability as a mediator of the relationship between access to information and SME sustainability. The result supports $\mathrm{H} 8(\beta=0.127, t=3.856, p=0.000$ and $\mathrm{CI}=0.074,0.202)$ and $\mathrm{H} 9(\beta=0.067, t=2.062, p=0.040$ and $\mathrm{CI}=0.015,0.138)$ but failed to accept $\mathrm{H} 4(\beta=-0.030, t=0.926, p=0.355$ and $\mathrm{CI}=-0.095,0.032)$. Finally, the study assessed management commitment as a moderator of the relationship between access to resources, access to information, and SME sustainability. The result supports H10 $(\beta=0.067, t=2.062, p=0.040$ and CI $=0.015,0.138)$ and failed to accept H11 ( $\beta=0.067, t=2.062, p=0.040$ and $\mathrm{CI}=0.015,0.138)$. 
Table 4. Hypothesis Testing.

\begin{tabular}{|c|c|c|c|c|c|c|c|c|c|}
\hline Hypothesis & Std. Beta & Std. Dev. & $t$-Values & $p$-Values & LLCI & ULCI & $f^{2}$ & VIF & Decision \\
\hline H1: Access to Resources $\rightarrow$ SMEs sustainability & -0.068 & 0.069 & 0.992 & 0.161 & -0.175 & 0.048 & 0.005 & 1.446 & Not supported \\
\hline H2: Access to Information $\rightarrow$ SMEs sustainability & 0.382 & 0.059 & 6.457 & 0.000 & 0.256 & 0.461 & 0.163 & 1.292 & Supported \\
\hline H3: Access to Information $\rightarrow$ Access to Resources & 0.438 & 0.068 & 6.393 & 0.000 & 0.318 & 0.539 & 0.237 & 1.000 & Supported \\
\hline H4: Access to Information $\rightarrow$ Access to Resources $\rightarrow$ SMEs sustainability & -0.030 & 0.032 & 0.926 & 0.355 & -0.095 & 0.032 & - & - & Not Supported \\
\hline H6: Access to Information $\rightarrow$ Innovation Capability & 0.205 & 0.086 & 2.373 & 0.009 & 0.083 & 0.369 & 0.047 & 1.239 & Supported \\
\hline H7: Innovation Capability $\rightarrow$ SMEs sustainability & 0.325 & 0.064 & 5.068 & 0.000 & 0.200 & 0.416 & 0.112 & 1.358 & Supported \\
\hline H8: Access to Resources $\rightarrow$ Innovation Capability $\rightarrow$ SMEs sustainability & 0.127 & 0.033 & 3.856 & 0.000 & 0.074 & 0.202 & - & - & Supported \\
\hline H9: Access to Information $\rightarrow$ Innovation Capability $\rightarrow$ SMEs sustainability & 0.067 & 0.032 & 2.062 & 0.040 & 0.015 & 0.138 & - & - & Supported \\
\hline H10: Access to Information*Management Com $\rightarrow$ Innovation Capability & 0.217 & 0.087 & 2.497 & 0.006 & 0.103 & 0.309 & - & - & Supported \\
\hline
\end{tabular}




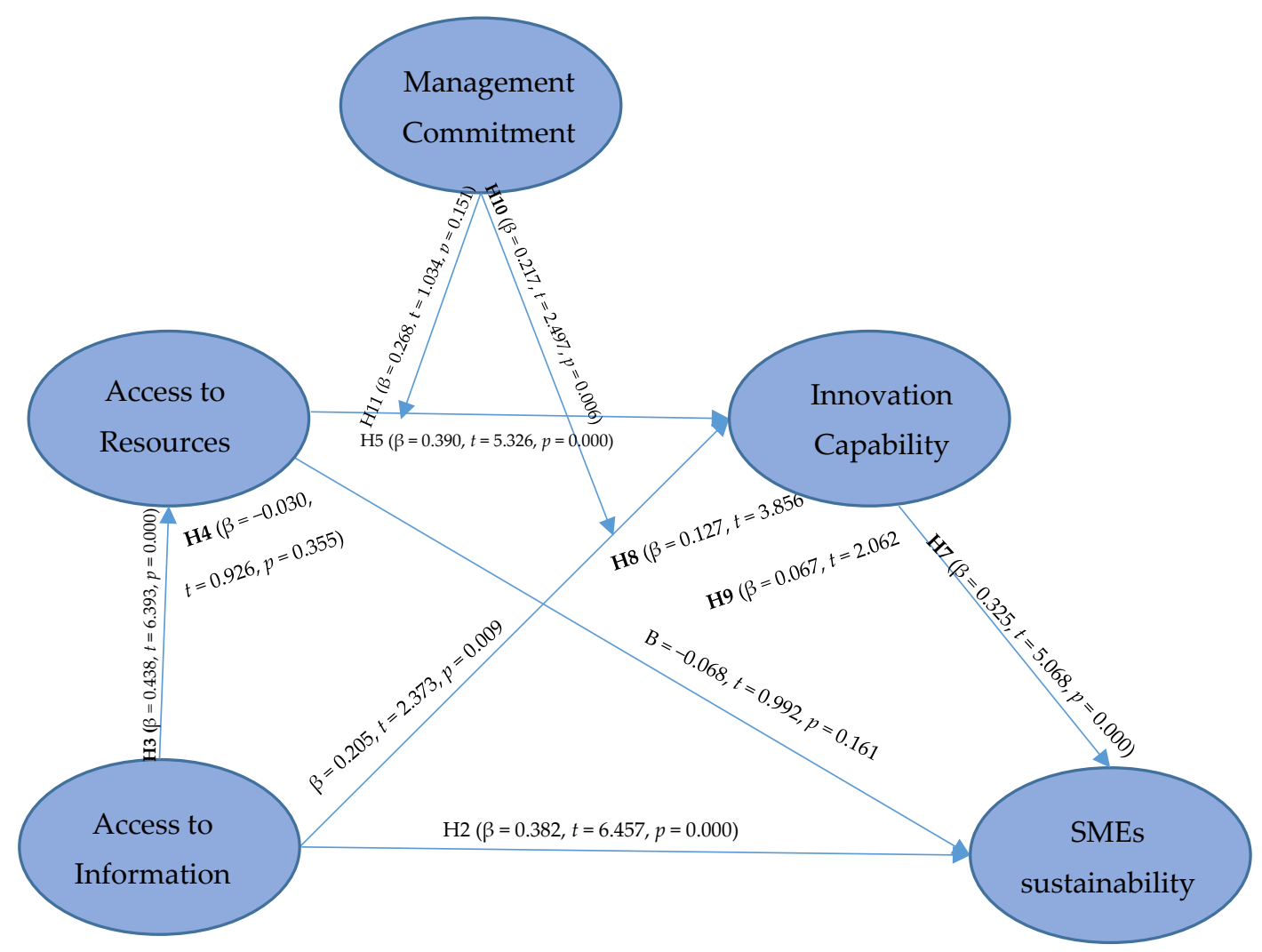

Figure 2. Results.

To assess the inner model, we examined the coefficient of determination $\left(R^{2}\right)$, effect size $\left(f^{2}\right)$ and predictive relevance $\left(Q^{2}\right)$, as presented in Table 5 . For the $R^{2}, 19 \%, 30 \%$ and $26 \%$ of the total variance of access to resources, SME sustainability, and innovation capability, respectively, were explained by their respective exogenous variables. For the $f^{2}$, as presented in Table 4 , when predicting SME sustainability, access to information contributes more to $f^{2}(0.163)$ than access to resources $f^{2}(0.005)$, and innovation capability $f^{2}(0.112)$. But when predicting innovation capability, access to resources contributes more to $R^{2}(0.169)$ than access to information (0.047). Finally, $Q^{2}$ was assessed using a blindfolding procedure. $Q_{2}$ values $>0$ mean that the predictor possesses the predictive relevance for the criterion variable [154]. The $Q^{2}$ values of the endogenous variables-access to resources, SME sustainability, and innovation capability-are $0.127,0.164$ and 0.153 , respectively, and are greater than zero, signifying that the research model has predictive relevance. Finally, the study assessed the model fit using the standardized root mean square residual (SRMR). The value of SRMR in this paper is 0.077, a value less than 0.08 [155], showing that the composite factor model fits the data.

Table 5. Coefficient of determination $\left(R^{2}\right)$ and predictive relevance $\left(Q^{2}\right)$.

\begin{tabular}{cccc}
\hline & Constructs & $\boldsymbol{R}^{\mathbf{2}}$ & $\boldsymbol{Q}^{\mathbf{2}}$ \\
\hline 2 & Access to Resources & 0.188 & 0.127 \\
3 & SME Sustainability & 0.295 & 0.164 \\
4 & Innovation Capability & 0.263 & 0.153 \\
\hline
\end{tabular}

\subsection{Moderating Effect of Management Commitment}

This study hypothesized management commitment would have a moderation influence on the relationships between access to resources, access to information, and innovation capability. Moderation analysis is assessed by applying an orthogonalization approach. As Table 4 shows, the results for the influence of the moderator on the access to information and innovation capability 
$(\beta=0.217, t=2.497, p=0.006$ and $\mathrm{CI}=0.103,0.309)$ and access to resources and innovation capability $(\beta=0.268, t=1.034, p=0.151$ and $C I=-0.195,0.132)$ relationships indicates that management commitment moderates the latter but not the former relationship. Hence, H10 was supported while H11 was not. The results show that the positive relationship between access to information and innovation capability is stronger when there is a high level of management commitment. Further, interaction effects need to be graphed to enable important interpretation [156], hence, Figure 3 show the plots of the two-way interactions. It illustrates that the relationship between access to information and the innovation capability of SMEs was moderated by management commitment.

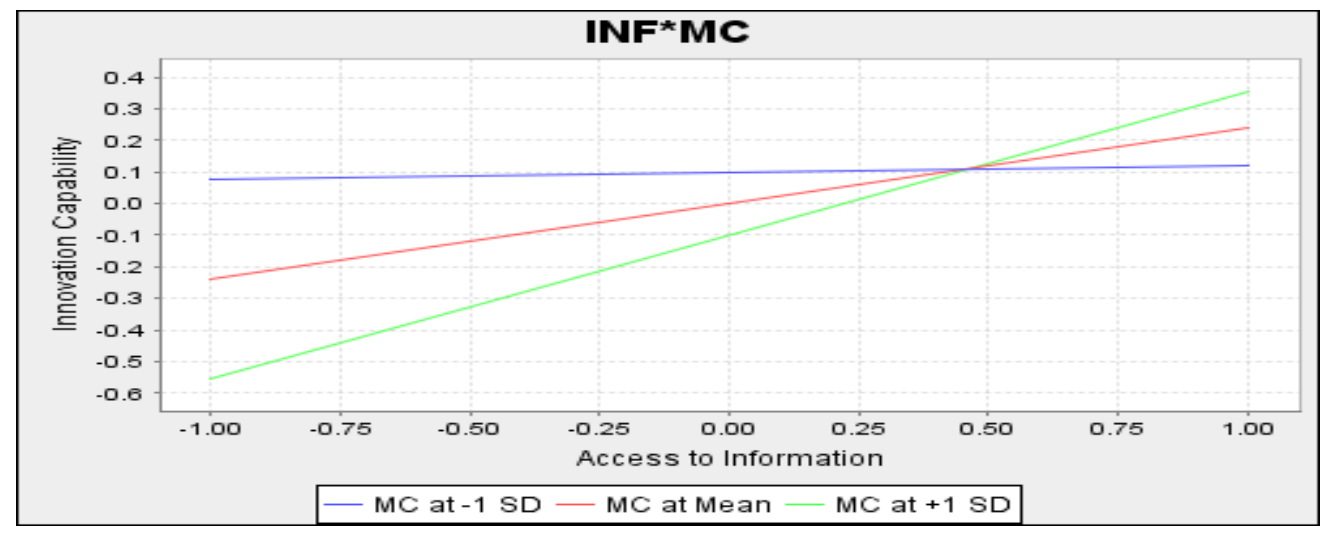

Figure 3. Effect between access to information and management commitment on innovation capability.

\section{Discussions and Conclusions}

This study has sought to tackle an important area in SME sustainability, and explore the importance of resources, information and innovation capabilities based on the NRBV. The study focuses on SMEs because, generally, the vast majority of studies in this area have concentrated on large firms, to the exclusion of SMEs [157].

The findings in this current research add to the existing literature by providing empirical evidence for the importance of accessing resources and information for innovation capability and sustainability, specific to SMEs. Although present-day scholars have highlighted a need to investigate the innovation capability and sustainability of SMEs, few studies have been carried out on this topic. Hence, the current research is one of the first study which tries to recognize the relationship among access to resources and information on innovation capability and sustainability of SMEs. Further, this present research explored how management commitment moderates the effect of resource and information access on innovation capability. Bearing in mind the focus of the present research, 11 hypotheses were tested. The results of the structural equation modelling support eight and fail to support three of these hypotheses. Specifically, in addition to the direct relationships among the variables, the study also tested the mediating role of access to resources and innovation capability, but only the latter mediates this relationship. The results also confirmed that management commitment does moderate the relationship between access to innovation and innovation capability, but not that between access to resources and innovation capability.

All the routes involving innovation capabilities were significant in this study, and this justifies the argument that innovation capability is an essential topic for both managers and policy makers, as well as academics [158]. Further, innovation capabilities are crucial elements for organizations to build and sustain a competitive advantage through sustainability, especially for those organizations in dynamic market environments. Innovation capabilities can support organizations to improve unique organizational processes. In addition, such capabilities may facilitate an organization's decision-makers to better handle environmental (social and technological) changes [159]. First, as hypothesized and according to previous findings $[159,160]$, the result shows that the links between access to resources and innovation capability and between access to information and innovation were significant. This means 
that to ensure that innovation activities are focused towards the needs of the market and organizational targets, building innovation capabilities must involve a solid set of resources (tangible and intangible), information, motivations, and abilities [159]. Second, the relationship of innovation capability and sustainability of SMEs is a developing research link focusing on innovation related to sustainability issues, which is critical to SMEs in developing countries. While prior studies have had inadequate knowledge about innovation capabilities for SME sustainability practices, this current study is one of the many attempts to bridge the gap of knowledge by theoretically hypothesizing and empirically authenticating innovation capability for sustainability in SMEs based on RBV and NRBV. Although studies on the relationship between innovation capability and sustainability have been well documented, most of these studies concentrated on the activities of larger organizations. This study tested this link on SMEs, and found the link was also significant. This result reinforces the previous study of Lai et al. [161], who found that innovation capability has a significant relationship with corporate sustainability.

As hypothesized, top management commitment positively moderates the relationship between access to resources, access to information, and innovation capability. SMEs with top management squads that stretch their support for innovation are committed to decreasing innovation capability concerns emanating from operations, regularly evaluate the innovation influences of operations, and comprehend a great deal about industry and competitors' innovation capabilities. This current finding is in line with past studies that have testified that implementing innovation capabilities tends to be mostly unsuccessful if top management commitment is neglected [162,163]. Further, the finding corroborates the findings of Wijethilake and Lama [163] and Aziz et al. [164], who opined that a top management team is an essential factor.

\subsection{Implications}

This study contributed practically, theoretically and methodologically to the research area. However, in respect of practical implications, this study highlights the pressing necessity to address management commitment considerations in terms of the SME scale, regarding it as a possible means by which an SME can gain organizational sustainability. According to this study, management commitment is important for access to information, which leads to positive SME innovative capability. Secondly the present study suggests to the owners/managers of small and medium firms that they should consider the effective use of information and resources to enhance their firm's innovative capability and SME sustainability. However, the management of small and medium firms should consider these variables before any decision towards the innovation culture inside the firms, which aims towards the sustainable performance of the SMEs, is made. In addition, strengthening the relationship between access to resources and access to information could improve the sustainable performance of SMEs. Particularly, SMEs should focus on their innovative capability. In other words, innovative capability is not only a response to the external environment, but it also deals with resources and information, which are important for the long-term sustainability of the SMEs.

Theoretically, this study contributed to the understanding of NRBV theory. There is little in the literature regarding the mediating-moderating role of innovation capability and management commitment between access to information, access to resources, and SME sustainability, especially in the context of Pakistan. Specifically, a lot has been documented in the management literature regarding management commitment, but relatively little has been put into print that considers and addresses management commitment in SMEs, and developing sustainability by way of the development of an operational and dynamic management commitment continuum. Therefore, this study contributes significantly in the strategic management area.

Methodologically, this study contributes to the body of knowledge by adopting the use of partial least squares based structural equation modelling (PLS-SEM) for conducting the analysis of the constructs involved. It was emphasized by Ali and Kim [165] that various articles issued in top journals have used other approaches, such as co-variance based structural equation modelling (CB-SEM). It is noteworthy that CB-SEM is so generally used that many scholars merely denote CB-SEM as SEM, 
disregarding the fact that PLS-SEM is a similarly essential approach [154]. Hence, the results back the opinions by a number of researchers that the PLS method should be absorbed, since it can model latent constructs under situations of complexity, non-normality, and small to medium sample sizes [166], maximizing the explained variance of the endogenous variables and the prediction of values for latent variables using multiple regressions [167]. Moreover, it is a fact that the current research adds to the methodological knowledge by making use of a freshly suggested measure to measure the discriminant validity of the constructs, the Heterotrait-Monotrait (HTMT) ratio of correlations [168], proposed after the traditional Fornell and Larcker [169] criterion failed to reliably detect the lack of discriminant validity in common research situations. Recently, Voorhees et al. [170] also recommended the use of HTMT as an improved tool for measuring discriminant validity.

\subsection{Limitations and Future Recommendations}

There are very clear limitations of this study, and for this reason we have some future recommendations. Firstly, information and resource access are described by the different manners by which people communicate with them, particularly the manners by which individuals look for and use them [117]. As a result, they incorporate both the acquiring of information and resources, and their utilization. Thus, access to data and assets should only be granted to those of constrained esteem, except if the expected recipient has the ability to utilize them [58]. More or less, access to information and resources is a fundamental, however not adequate, condition. It is the utilization of data and assets that conveys advantages. Hence, a future study could explore the resources and information usage related to the sustainability of SMEs to overcome the limitations of less access to information and resources.

Secondly, there are gender differences in terms of access to both resources and information [171]. Businesses owned or managed by females do not have the same access to information and resources as their male-owned counterparts. Lack of equal access puts these organizations at a disadvantage in competing with male-owned and managed firms, and this is a second limitation for the study. However, the literature is silent about this gender issue for the sustainability of firms. Therefore, future studies could explore this scarceness. Third, this study focuses on SMEs in Pakistan. Future studies could opt for a multi-country approach to allow for appraisals of SMEs in different contexts. Fourth, the current study only focused on SMEs, while future studies could involve larger firms in the sample. Fifth, this study is limited to cross-sectional data collection. However, a future study should adopt longitudinal methodology for data collection, to explore the in-depth understanding of the investigated framework in a different time frame.

Further future recommendations are still being discussed, as this study is a first attempt to integrate the access to resources and information, innovation capability, management commitment, and sustainability of SMEs into one research model to examine their relationships. Yet, this needs to be improved in future studies. Moreover, interrelationships between innovation capability and contextual factors may then also arise. Scholars may also find an advantage by applying the theoretical contribution of the current study to a comprehensive quantitative investigation, to test the potential effect of innovation capability and its inter-connections with other factors of sustainability behavior.

\section{Constructs Items}

\section{Sustainability}

1. Is your organization/company involved in improving the community/world in the non-business environment?

2. Do you agree that sustainability is important to your organization?

3. Is there an existing sustainability plan for your organization?

4. Do you think that having a sustainability manager/officer for your company is important?

5. Do you think your institution treats your employees fairly (such as involvement, reward, respect, participation in decision making)? 


\section{Access to Information}

1. The amount of information available to me is sufficient for me to make good decisions.

2. Most information I receive is very valuable.

3. I have found that information is generally complete enough for me to make good decisions.

4. I have full confidence that I make decisions based on accurate information

\section{Access to Resources}

1. I can obtain the resources necessary to support new ideas

2. When I need additional resources to do my job, I can usually get them.

3. I have access to the resources I need to do my job

\section{Innovation Capability}

1. To try out new ideas.

2. To seek new ways of doing things

3. To be creative in firm's operating methods

4. To develop new products and services

5. Perception of innovation as not risky and therefore acceptable

6. Increasing introduction of new products in the last five years

\section{Management Commitment}

1. How committed are you to your organization?

2. To what extent do you care about your organization?

3. How dedicated are you to your organization?

To what extent have you chosen to be committed to your organization?

Author Contributions: M.I. conceptualize, investigate, project administration and writing-review \& editing; I.S. Writing original draft, formal analysis and software; H.D.A. Data curation, methodology and supervision; J.I. Supervision, validation and methodology; I.H. Data curation, resources and supervision.

Funding: This research received no external funding.

Conflicts of Interest: The authors declare no conflict of interest.

\section{References}

1. OECD. Enhancing The Contributions of SMEs in a Global and Digitalized Economy; OECD: Paris, France, 2017.

2. Olszak, C.M.; Ziemba, E. The conceptual model of a web learning portal for small and medium sized enterprises. Issues Inf. Sci. Inf. Technol. 2008, 5, 335-351.

3. Jahanshahi, A.A.; Brem, A. Sustainability in SMEs: Top management teams behavioral integration as source of innovativeness. Sustainability 2017, 9, 1899. [CrossRef]

4. Ngah, R.; Abd Wahab, I.; Salleh, Z. The Sustainable Competitive Advantage of Small and Medium Entreprises (SMEs) with Intellectual Capital, Knowledge Management and Innovative Intelligence: Building a Conceptual Framework. Adv. Sci. Lett. 2015, 21, 1325-1328. [CrossRef]

5. Solberg Hjorth, S.; Brem, A. How to assess market readiness for an innovative solution: The case of heat recovery technologies for SMEs. Sustainability 2016, 8, 1152. [CrossRef]

6. Gold, S.; Trautrims, A.; Trodd, Z. Modern slavery challenges to supply chain management. Supply Chain Manag. Int. J. 2015, 20, 485-494. [CrossRef]

7. Mian, S.A.; Qureshi, S.M. Global Entrepenuership Monitor Pakistan Report 2011; Institue of Business Administration: Karachi, Pakistan, 2012.

8. Bansal, P. Evolving sustainably: A longitudinal study of corporate sustainable development. Strateg. Manag. J. 2005, 26, 197-218. [CrossRef] 
9. Wang, J.; Zhang, Y.; Goh, M. Moderating the Role of Firm Size in Sustainable Performance Improvement through Sustainable Supply Chain Management. Sustainability 2018, 10, 1654. [CrossRef]

10. Hörisch, J.; Johnson, M.P.; Schaltegger, S. Implementation of sustainability management and company size: A knowledge-based view. Bus. Strategy Environ. 2015, 24, 765-779. [CrossRef]

11. Henriques, I.; Sadorsky, P. The relationship between environmental commitment and managerial perceptions of stakeholder importance. Acad. Manag. J. 1999, 42, 87-99.

12. Midgett, C.; Deale, C.S.; Crawford, A.; Weber, M.; Bendickson, J. A cross-case analysis of barriers to sustainability in small tourism accommodation enterprises in Dare County, North Carolina. Tour. Hosp. Res. 2019, 1467358419831425. [CrossRef]

13. Font, X.; Garay, L.; Jones, S. Sustainability motivations and practices in small tourism enterprises in European protected areas. J. Clean. Prod. 2016, 137, 1439-1448. [CrossRef]

14. Williams, S.; Schaefer, A. Small and medium-sized enterprises and sustainability: Managers' values and engagement with environmental and climate change issues. Bus. Strategy Environ. 2013, 22, 173-186. [CrossRef]

15. Kornilaki, M.; Thomas, R.; Font, X. The sustainability behaviour of small firms in tourism: The role of self-efficacy and contextual constraints. J. Sustain. Tour. 2019, 27, 1-21. [CrossRef]

16. Yahya, N. Agricultural 4.0: Its Implementation Toward Future Sustainability. In Green Urea; Springer: Berlin, Germany, 2018; pp. 125-145.

17. Raj, R.; Wong, S.H.S.; Beaumont, A.J. Empowering SMEs to Make Better Decisions with Business Intelligence: A Case Study. In Proceedings of the International Joint Conference on Knowledge Discovery, Knowledge Engineering, and Knowledge Management, Porto, Portugal, 9-11 November 2016; pp. 306-325.

18. World Bank. World Bank Supports Increased Financing for Medium and Small Businesses in Nigeria; Press Release; World Bank: Washington, DC, USA, 2014.

19. Primo, N.; Khan, A.W. Gender Issues in the Information Society; UNESCO: Paris, France, 2003.

20. Shiferaw, B.; Kebede, T.; Kassie, M.; Fisher, M. Market imperfections, access to information and technology adoption in Uganda: Challenges of overcoming multiple constraints. Agric. Econ. 2015, 46, 475-488. [CrossRef]

21. Salancik, G.R.; Pfeffer, J. A social information processing approach to job attitudes and task design. Admin. Sci. Q. 1978, 23, 224-253. [CrossRef]

22. Jayawarna, D.; Jones, O.; Macpherson, A. New business creation and regional development: Enhancing resource acquisition in areas of social deprivation. Entrep. Reg. Dev. 2011, 23, 735-761. [CrossRef]

23. Gedajlovic, E.; Honig, B.; Moore, C.B.; Payne, G.T.; Wright, M. Social capital and entrepreneurship: A schema and research agenda. Entrep. Theory Pract. 2013, 37, 455-478. [CrossRef]

24. Dai, S.; Xue, H.; Jiang, Y.; Zhang, W.; Zhang, X. Sustainable Entrepreneurship Team Scale Development: A Complex Systems Perspective. Sustainability 2018, 10, 4199. [CrossRef]

25. Grossman, E.B.; Yli-Renko, H.; Janakiraman, R. Resource search, interpersonal similarity, and network tie valuation in nascent entrepreneurs' emerging networks. J. Manag. 2012, 38, 1760-1787. [CrossRef]

26. Aldrich, H.E.; Martinez, M. Entrepreneurship as social construction: A multi-level evolutionary approach. In Handbook of Entrepreneurship Research; Springer: Berlin, Germany, 2003; pp. 359-399.

27. De Clercq, D.; Lim, D.S.; Oh, C.H. Individual-Level Resources and New Business Activity: The Contingent Role of Institutional Context. Entrep. Theory Pract. 2013, 37, 303-330. [CrossRef]

28. Edelman, L.; Yli-Renko, H. The impact of environment and entrepreneurial perceptions on venture-creation efforts: Bridging the discovery and creation views of entrepreneurship. Entrep. Theory Pract. 2010, 34, 833-856. [CrossRef]

29. Ireland, R.D.; Hitt, M.A.; Sirmon, D.G. A model of strategic entrepreneurship: The construct and its dimensions. J. Manag. 2003, 29, 963-989.

30. Shane, S.A. A General Theory of Entrepreneurship: The Individual-Opportunity Nexus; Edward Elgar Publishing: Cheltenham, UK, 2003.

31. Spreitzer, G.M. Social structural characteristics of psychological empowerment. Acad. Manag. J. 1996, 39, 483-504.

32. Forsman, H. Innovation capacity and innovation development in small enterprises. A comparison between the manufacturing and service sectors. Res. Policy 2011, 40, 739-750. [CrossRef] 
33. Love, J.H.; Roper, S. SME innovation, exporting and growth: A review of existing evidence. Int. Small Bus. J. 2015, 33, 28-48. [CrossRef]

34. Chen, Y.; Wang, Y.; Nevo, S.; Benitez-Amado, J.; Kou, G. IT capabilities and product innovation performance: The roles of corporate entrepreneurship and competitive intensity. Inf. Manag. 2015, 52, 643-657. [CrossRef]

35. Camisón, C.; Villar-López, A. Organizational innovation as an enabler of technological innovation capabilities and firm performance. J. Bus. Res. 2014, 67, 2891-2902. [CrossRef]

36. Kim, M.-K.; Park, J.-H.; Paik, J.-H. Factors influencing innovation capability of small and medium-sized enterprises in Korean manufacturing sector: Facilitators, barriers and moderators. Int. J. Technol. Manag. 2018, 76, 214-235. [CrossRef]

37. Battisti, M.; Perry, M. Walking the talk? Environmental responsibility from the perspective of small-business owners. Corp. Soc. Responsib. Environ. Manag. 2011, 18, 172-185. [CrossRef]

38. Vernon, D.; Egner, T.; Cooper, N.; Compton, T.; Neilands, C.; Sheri, A.; Gruzelier, J. The effect of training distinct neurofeedback protocols on aspects of cognitive performance. Int. J. Psychophysiol. 2003, 47, 75-85. [CrossRef]

39. Kanter, R.M. Change Masters; Simon and Schuster: New York, NY, USA, 1984.

40. Cooper, A.C.; Folta, T.B.; Woo, C. Entrepreneurial information search. J. Bus. Vent. 1995, 10, $107-120$. [CrossRef]

41. Amit, R.; Schoemaker, P.J. Strategic assets and organizational rent. Strateg. Manag. J. 1993, 14, 33-46. [CrossRef]

42. Barney, J. Firm resources and sustained competitive advantage. J. Manag. 1991, 17, 99-120. [CrossRef]

43. Peteraf, M.A. The cornerstones of competitive advantage: A resource-based view. Strateg. Manag. J. 1993, 14, 179-191. [CrossRef]

44. Wernerfelt, B. A resource-based view of the firm. Strateg. Manag. J. 1984, 5, 171-180. [CrossRef]

45. Powell, T.C. Competitive advantage: Logical and philosophical considerations. Strateg. Manag. J. 2001, 22, 875-888. [CrossRef]

46. Darnall, N.; Edwards, D., Jr. Predicting the cost of environmental management system adoption: The role of capabilities, resources and ownership structure. Strateg. Manag. J. 2006, 27, 301-320. [CrossRef]

47. Zhu, Q.; Sarkis, J.; Lai, K.h.; Geng, Y. The role of organizational size in the adoption of green supply chain management practices in China. Corp. Soc. Responsib. Environ. Manag. 2008, 15, 322-337. [CrossRef]

48. Chakrabarty, S.; Wang, L. The long-term sustenance of sustainability practices in MNCs: A dynamic capabilities perspective of the role of R\&D and internationalization. J. Bus. Ethics 2012, 110, 205-217.

49. Falkenberg, J.; Brunsæl, P. Corporate social responsibility: A strategic advantage or a strategic necessity? J. Bus. Ethics 2011, 99, 9-16. [CrossRef]

50. Uhlaner, L.M.; Berent-Braun, M.M.; Jeurissen, R.J.; de Wit, G. Beyond size: Predicting engagement in environmental management practices of Dutch SMEs. J. Bus. Ethics 2012, 109, 411-429. [CrossRef]

51. Galani, D.; Gravas, E.; Stavropoulos, A. Company characteristics and environmental policy. Bus. Strategy Environ. 2012, 21, 236-247. [CrossRef]

52. Torugsa, N.A.; O'Donohue, W.; Hecker, R. Proactive CSR: An empirical analysis of the role of its economic, social and environmental dimensions on the association between capabilities and performance. J. Bus. Ethics 2013, 115, 383-402. [CrossRef]

53. Bowen, F.E. Does size matter? Organizational slack and visibility as alternative explanations for environmental responsiveness. Bus. Soc. 2002, 41, 118-124. [CrossRef]

54. Spence, L.J. Does size matter? The state of the art in small business ethics. Bus. Ethics Eur. Rev. 1999, 8, 163-174. [CrossRef]

55. Lepoutre, J.; Heene, A. Investigating the impact of firm size on small business social responsibility: A critical review. J. Bus. Ethics 2006, 67, 257-273. [CrossRef]

56. Udayasankar, K. Corporate social responsibility and firm size. J. Bus. Ethics 2008, 83, 167-175. [CrossRef]

57. Golicic, S.L.; Smith, C.D. A meta-analysis of environmentally sustainable supply chain management practices and firm performance. J. Supply Chain Manag. 2013, 49, 78-95. [CrossRef]

58. Hart, S.L. A natural-resource-based view of the firm. Acad. Manag. Rev. 1995, 20, 986-1014. [CrossRef]

59. Hart, S.L.; Dowell, G. Invited editorial: A natural-resource-based view of the firm: Fifteen years after. J. Manag. 2011, 37, 1464-1479. [CrossRef] 
60. Colicchia, C.; Marchet, G.; Melacini, M.; Perotti, S. Building environmental sustainability: Empirical evidence from Logistics Service Providers. J. Clean. Prod. 2013, 59, 197-209. [CrossRef]

61. Demirel, P.; Kesidou, E. Sustainability-oriented capabilities for eco-innovation: Meeting the regulatory, technology, and market demands. Bus. Strategy Environ. 2018. [CrossRef]

62. Birou, L.M.; Green, K.W.; Inman, R.A. Sustainability knowledge and training: Outcomes and firm performance. J. Manuf. Technol. Manag. 2019, 30, 294-311. [CrossRef]

63. Rao, P.; Holt, D. Do green supply chains lead to competitiveness and economic performance? Int. J. Oper. Prod. Manag. 2005, 25, 898-916. [CrossRef]

64. Ruiz-Benitez, R.; López, C.; Real, J.C. Achieving sustainability through the lean and resilient management of the supply chain. Int. J. Phys. Distrib. Logist. Manag. 2019, 49, 122-155. [CrossRef]

65. Johnson, M.P. Sustainability management and small and medium-sized enterprises: Managers' awareness and implementation of innovative tools. Corp. Soc. Responsib. Environ. Manag. 2015, 22, 271-285. [CrossRef]

66. Lozano, R.; Carpenter, A.; Huisingh, D. A review of 'theories of the firm' and their contributions to Corporate Sustainability. J. Clean. Prod. 2015, 106, 430-442. [CrossRef]

67. Smith, P.A.; Sharicz, C. The shift needed for sustainability. Learn. Organ. 2011, 18, 73-86. [CrossRef]

68. Labuschagne, C.; Brent, A.C. Sustainable project life cycle management: The need to integrate life cycles in the manufacturing sector. Int. J. Proj. Manag. 2005, 23, 159-168. [CrossRef]

69. Starik, M.; Kanashiro, P. Toward a theory of sustainability management: Uncovering and integrating the nearly obvious. Organ. Environ. 2013, 26, 7-30. [CrossRef]

70. Beddoe, R.; Costanza, R.; Farley, J.; Garza, E.; Kent, J.; Kubiszewski, I.; Martinez, L.; McCowen, T.; Murphy, K.; Myers, N. Overcoming systemic roadblocks to sustainability: The evolutionary redesign of worldviews, institutions, and technologies. Proc. Natl. Acad. Sci. USA 2009, 106, 2483-2489. [CrossRef]

71. Homans, G.C. Social behavior as exchange. Am. J. Sociol. 1958, 63, 597-606. [CrossRef]

72. Bowen, D.E.; Lawler, E.E., III. Total quality-oriented human resources management. Organ. Dyn. 1992, 20, 29-41. [CrossRef]

73. Gist, M.E.; Mitchell, T.R. Self-efficacy: A theoretical analysis of its determinants and malleability. Acad. Manag. Rev. 1992, 17, 183-211. [CrossRef]

74. Huang, L.; Knight, A.P. Resources and relationships in entrepreneurship: An exchange theory of the development and effects of the entrepreneur-investor relationship. Acad. Manag. Rev. 2017, 42, 80-102. [CrossRef]

75. Zott, C.; Huy, Q.N. How entrepreneurs use symbolic management to acquire resources. Admin. Sci. Q. 2007, 52, 70-105. [CrossRef]

76. Anderson, B.S.; Eshima, Y. The influence of firm age and intangible resources on the relationship between entrepreneurial orientation and firm growth among Japanese SMEs. J. Bus. Ventur. 2013, 28, 413-429. [CrossRef]

77. Phillips, M.; Moos, M.; Nieman, G. The impact of government support initiatives on the growth of female businesses in Tshwane South Africa. Mediterr. J. Soc. Sci. 2014, 5, 85. [CrossRef]

78. Tello, S.; Yang, Y.; Latham, S. Nascent entrepreneurs access and use of network resources in a technology incubator. J. Small Bus. Entrep. 2012, 25, 375-397. [CrossRef]

79. Villanueva, J.; Van de Ven, A.H.; Sapienza, H.J. Resource mobilization in entrepreneurial firms. J. Bus. Ventur. 2012, 27, 19-30. [CrossRef]

80. Hunt, S.D.; Morgan, R.M. The comparative advantage theory of competition. J. Market. 1995, 59, 1-15. [CrossRef]

81. Ropega, J. The reasons and symptoms of failure in SME. Int. Adv. Econ. Res. 2011, 17, 476-483. [CrossRef]

82. Ulhøi, J.P. The social dimensions of entrepreneurship. Technovation 2005, 25, 939-946. [CrossRef]

83. Child, J.; Hsieh, L.H. Decision mode, information and network attachment in the internationalization of SMEs: A configurational and contingency analysis. J. World Bus. 2014, 49, 598-610. [CrossRef]

84. McNab, A.L.; Ladd, D.A. Information quality: The importance of context and trade-offs. In Proceedings of the 2014 47th Hawaii International Conference on System Sciences, Waikoloa, HI, USA, 6-9 January 2014; pp. 3525-3532.

85. Valacich, J.; Schneider, C. Information Systems Today: Managing in the Digital World with MyITLab; Prentice Hall Press: Upper Saddle River, NJ, USA, 2014. 
86. Irvine, W.; Anderson, A.R. ICT (information communication technology), peripherality and smaller hospitality businesses in Scotland. Int. J. Entrep. Behav. Res. 2008, 14, 200-218. [CrossRef]

87. Christopher, M.; Lee, H. Mitigating supply chain risk through improved confidence. Int. J. Phys. Distrib. Logist. Manag. 2004, 34, 388-396. [CrossRef]

88. Potnis, D.D. Beyond access to information: Understanding the use of information by poor female mobile users in rural India. Inf. Soc. 2015, 31, 83-93. [CrossRef]

89. Stam, W.; Arzlanian, S.; Elfring, T. Social capital of entrepreneurs and small firm performance: A meta-analysis of contextual and methodological moderators. J. Bus. Vent. 2014, 29, 152-173. [CrossRef]

90. Autio, E.; Dahlander, L.; Frederiksen, L. Information exposure, opportunity evaluation, and entrepreneurial action: An investigation of an online user community. Acad. Manag. J. 2013, 56, 1348-1371. [CrossRef]

91. Avram, E.; Priescu, I. Access to information and empowerment perspectives in health services. Procedia-Soc. Behav. Sci. 2012, 33, 949-953. [CrossRef]

92. Laužikas, M.; Dailydaitè, S. Impacts of social capital on transformation from efficiency to innovation-driven business. J. Bus. Econ. Manag. 2015, 16, 37-51. [CrossRef]

93. Bendoly, E.; Swink, M. Moderating effects of information access on project management behavior, performance and perceptions. J. Oper. Manag. 2007, 25, 604-622. [CrossRef]

94. Chen, M.-H.; Chang, Y.-Y.; Lee, C.-Y. Creative entrepreneurs' guanxi networks and success: Information and resource. J. Bus. Res. 2015, 68, 900-905. [CrossRef]

95. Jenssen, J.I.; Koenig, H.F. The effect of social networks on resource access and business start-ups. Eur. Plan. Stud. 2002, 10, 1039-1046. [CrossRef]

96. Kirzner, I.M. Entrepreneurial discovery and the competitive market process: An Austrian approach. J. Econ. Lit. 1997, 35, 60-85.

97. Bhagavatula, S.; Elfring, T.; Van Tilburg, A.; Van De Bunt, G.G. How social and human capital influence opportunity recognition and resource mobilization in India's handloom industry. J. Bus. Ventur. 2010, 25, 245-260. [CrossRef]

98. Stango, V.; Zinman, J. The Price is not Right (not even on Average): Exponential Growth Bias, Present-Biased Perceptions and Household Finance; Working Paper, Dartmouth College; Dartmouth College: Hanover, NH, USA, 2008.

99. Lau, V.P.; Shaffer, M.A.; Au, K. Entrepreneurial career success from a Chinese perspective: Conceptualization, operationalization, and validation. J. Int. Bus. Stud. 2007, 38, 126-146. [CrossRef]

100. Cefis, E.; Marsili, O. Survivor: The role of innovation in firms' survival. Res. Policy 2006, 35, 626-641. [CrossRef]

101. Bullinger, H.-J.; Bannert, M.; Brunswicker, S. Managing innovation capability in SMEs. Tech Monit. Spec. Feature Innov. KM SMEs May-June 2007, 17-27.

102. Evangelista, R.; Vezzani, A. The economic impact of technological and organizational innovations. A firm-level analysis. Res. Policy 2010, 39, 1253-1263. [CrossRef]

103. Burgelman, R.A.; Maidique, M.A.; Wheelwright, S.C. Strategic Management of Technology and Innovation; Irwin: Chicago, IL, USA, 1996; Volume 2.

104. Castela, B.M.; Ferreira, F.A.; Ferreira, J.J.; Marques, C.S. Assessing the innovation capability of small-and medium-sized enterprises using a non-parametric and integrative approach. Manag. Decis. 2018, 56, 1365-1383. [CrossRef]

105. Halme, M.; Korpela, M. Responsible innovation toward sustainable development in small and medium-sized enterprises: A resource perspective. Bus. Strategy Environ. 2014, 23, 547-566. [CrossRef]

106. Petruzzelli, A.M.; Ardito, L.; Savino, T. Maturity of knowledge inputs and innovation value: The moderating effect of firm age and size. J. Bus. Res. 2018, 86, 190-201. [CrossRef]

107. Hadjimanolis, A. Barriers to innovation for SMEs in a small less developed country (Cyprus). Technovation 1999, 19, 561-570. [CrossRef]

108. Galia, F.; Legros, D. Complementarities between obstacles to innovation: Evidence from France. Res. Policy 2004, 33, 1185-1199. [CrossRef]

109. Madrid-Guijarro, A.; Garcia, D.; Van Auken, H. Barriers to innovation among Spanish manufacturing SMEs. J. Small Bus. Manag. 2009, 47, 465-488. [CrossRef]

110. Elmquist, M.; Le Masson, P. The value of a 'failed'R\&D project: An emerging evaluation framework for building innovative capabilities. REd Manag. 2009, 39, 136-152. 
111. Caloghirou, Y.; Kastelli, I.; Tsakanikas, A. Internal capabilities and external knowledge sources: Complements or substitutes for innovative performance? Technovation 2004, 24, 29-39. [CrossRef]

112. Kang, K.H.; Kang, J. How do firms source external knowledge for innovation? Analysing effects of different knowledge sourcing methods. Int. J. Innov. Manag. 2009, 13, 1-17. [CrossRef]

113. Schaltegger, S. Sustainability as a driver for corporate economic success: Consequences for the development of sustainability management control. Soc. Econ. 2011, 33, 15-28. [CrossRef]

114. Schaltegger, S.; Wagner, M. Sustainable entrepreneurship and sustainability innovation: Categories and interactions. Bus. Strategy Environ. 2011, 20, 222-237. [CrossRef]

115. Bendul, J.C.; Rosca, E.; Pivovarova, D. Sustainable supply chain models for base of the pyramid. J. Clean. Prod. 2017, 162, S107-S120. [CrossRef]

116. Rosca, E.; Arnold, M.; Bendul, J.C. Business models for sustainable innovation-An empirical analysis of frugal products and services. J. Clean. Prod. 2017, 162, S133-S145. [CrossRef]

117. Zhang, M.; Pawar, K.S.; Bhardwaj, S. Improving supply chain social responsibility through supplier development. Prod. Plan. Control 2017, 28, 500-511. [CrossRef]

118. WCED, S.W.S. World commission on environment and development. Our Common Future 1987, 17, 1-91.

119. Brem, A.; Ivens, B. Do frugal and reverse innovation foster sustainability? Introduction of a conceptual framework. J. Technol. Manag. Grow. Econ. 2013, 4, 31-50.

120. Ardito, L.; Messeni Petruzzelli, A.; Pascucci, F.; Peruffo, E. Inter-firm R\&D collaborations and green innovation value: The role of family firms' involvement and the moderating effects of proximity dimensions. Bus. Strategy Environ. 2019, 28, 185-197.

121. Van de Wetering, R.; Mikalef, P.; Helms, R. Driving organizational sustainability-oriented innovation capabilities: A complex adaptive systems perspective. Curr. Opin. Environ. Sustain. 2017, 28, 71-79. [CrossRef]

122. Rahman, M.; Doroodian, M.; Kamarulzaman, Y.; Muhamad, N. Designing and validating a model for measuring sustainability of overall innovation capability of small and medium-sized enterprises. Sustainability 2015, 7, 537-562. [CrossRef]

123. Hontou, V.; Diakoulaki, D.; Papagiannakis, L. A multicriterion classification approach for assessing the impact of environmental policies on the competitiveness of firms. Corp. Soc. Responsib. Environ. Manag. 2007, 14, 28-41. [CrossRef]

124. Van Kleef, J.A.; Roome, N.J. Developing capabilities and competence for sustainable business management as innovation: A research agenda. J. Clean. Prod. 2007, 15, 38-51. [CrossRef]

125. Newbert, S.L. Value, rareness, competitive advantage, and performance: A conceptual-level empirical investigation of the resource-based view of the firm. Strateg. Manag. J. 2008, 29, 745-768. [CrossRef]

126. González-Benito, J.; González-Benito, Ó. A study of determinant factors of stakeholder environmental pressure perceived by industrial companies. Bus. Strategy Environ. 2010, 19, 164-181. [CrossRef]

127. Chadwick, C.; Super, J.F.; Kwon, K. Resource orchestration in practice: CEO emphasis on SHRM, commitment-based HR systems, and firm performance. Strateg. Manag. J. 2015, 36, 360-376. [CrossRef]

128. Jayaram, J.; Oke, A.; Prajogo, D. The antecedents and consequences of product and process innovation strategy implementation in Australian manufacturing firms. Int. J. Prod. Res. 2014, 52, 4424-4439. [CrossRef]

129. Kuratko, D.F.; Covin, J.G.; Hornsby, J.S. Why implementing corporate innovation is so difficult. Bus. Horiz. 2014, 57, 647-655. [CrossRef]

130. Colwell, S.R.; Joshi, A.W. Corporate ecological responsiveness: Antecedent effects of institutional pressure and top management commitment and their impact on organizational performance. Bus. Strategy Environ. 2013, 22, 73-91. [CrossRef]

131. Dubey, R.; Gunasekaran, A.; Childe, S.J.; Papadopoulos, T.; Helo, P. Supplier relationship management for circular economy: Influence of external pressures and top management commitment. Manag. Decis. 2018. [CrossRef]

132. Jabbour, C.J.C.; Santos, F.C.A. The central role of human resource management in the search for sustainable organizations. Int. J. Hum. Resourc. Manag. 2008, 19, 2133-2154. [CrossRef]

133. Ramus, C.A.; Killmer, A.B. Corporate greening through prosocial extrarole behaviours-a conceptual framework for employee motivation. Bus. Strategy Environ. 2007, 16, 554-570. [CrossRef] 
134. Graves, L.M.; Sarkis, J.; Gold, N. Employee proenvironmental behavior in Russia: The roles of top management commitment, managerial leadership, and employee motives. Resour. Conserv. Recycl. 2019, 140, 54-64. [CrossRef]

135. Podsakoff, P.M.; MacKenzie, S.B.; Podsakoff, N.P. Sources of method bias in social science research and recommendations on how to control it. Annu. Rev. Psychol. 2012, 63, 539-569. [CrossRef]

136. Chin, W.W. How to write up and report PLS analyses. In Handbook of Partial Least Squares; Springer: Berlin, Germany, 2010; pp. 655-690.

137. Faul, F.; Erdfelder, E.; Buchner, A.; Lang, A.-G. Statistical power analyses using G* Power 3.1: Tests for correlation and regression analyses. Behav. Res. Methods 2009, 41, 1149-1160. [CrossRef]

138. Faul, F.; Erdfelder, E.; Lang, A.-G.; Buchner, A. G* Power 3: A flexible statistical power analysis program for the social, behavioral, and biomedical sciences. Behav. Res. Methods 2007, 39, 175-191. [CrossRef]

139. Cohen, J. Statistical Power Analysis for the Behavioral Sciences; Lawrence Erlbaum Associates: Hillsdale, NJ, USA, 1988.

140. Hair, J.F., Jr.; Sarstedt, M.; Hopkins, L.; Kuppelwieser, V.G. Partial least squares structural equation modeling (PLS-SEM) An emerging tool in business research. Eur. Bus. Rev. 2014, 26, 106-121. [CrossRef]

141. Mishra, P.; Sharma, S.K.; Swami, S. Antecedents and consequences of organizational politics: A select study of a central university. J. Adv. Manag. Res. 2016, 13, 334-351. [CrossRef]

142. Hair, J.F.; Ringle, C.M.; Sarstedt, M. Partial least squares: The better approach to structural equation modeling? Long Range Plan. 2012, 45, 312-319. [CrossRef]

143. Harmon, J.; Fairfield, K.; Wirtenberg, J. Missing an Opportunity; Institute for Sustainable Enterprises: Madison, NJ, USA, 2009.

144. Karkoulian, S.; Assaker, G.; Hallak, R. An empirical study of 360-degree feedback, organizational justice, and firm sustainability. J. Bus. Res. 2016, 69, 1862-1867. [CrossRef]

145. El Haddad, R.; Karkoulian, S.; Nehme, R. The impact of 360 feedback appraisal system on organizational justice and sustainability: The mediating roles of gender and managerial levels. Int. J. Organ. Anal. 2018. [CrossRef]

146. Yuan, Y.C.; Fulk, J.; Monge, P.R. Access to information in connective and communal transactive memory systems. Commun. Res. 2007, 34, 131-155. [CrossRef]

147. Calantone, R.J.; Cavusgil, S.T.; Zhao, Y. Learning orientation, firm innovation capability, and firm performance. Ind. Market. Manag. 2002, 31, 515-524. [CrossRef]

148. Klein, H.J.; Cooper, J.T.; Molloy, J.C.; Swanson, J.A. The assessment of commitment: Advantages of a unidimensional, target-free approach. J. Appl. Psychol. 2014, 99, 222. [CrossRef]

149. Klein, H.J.; Molloy, J.C.; Brinsfield, C.T. Reconceptualizing workplace commitment to redress a stretched construct: Revisiting assumptions and removing confounds. Acad. Manag. Rev. 2012, 37, 130-151.

150. Kock, N. Common method bias in PLS-SEM: A full collinearity assessment approach. Int. J. e-Collab. (IJeC) 2015, 11, 1-10. [CrossRef]

151. Hair, J.; Hollingsworth, C.L.; Randolph, A.B.; Chong, A.Y.L. An updated and expanded assessment of PLS-SEM in information systems research. Ind. Manag. Data Syst. 2017, 117, 442-458. [CrossRef]

152. Gold, A.H.; Malhotra, A.; Segars, A.H. Knowledge management: An organizational capabilities perspective. J. Manag. Inf. Syst. 2001, 18, 185-214. [CrossRef]

153. Kline, R.B. Principles and Practice of Structural Equation Modeling; Guilford Publications: New York, NY, USA, 2015.

154. Hair, J.F., Jr.; Hult, G.T.M.; Ringle, C.; Sarstedt, M. A Primer on Partial Least Squares Structural Equation Modeling (PLS-SEM); Sage Publications: Thousand Oaks, CA, USA, 2016.

155. Hu, L.T.; Bentler, P.M. Cutoff criteria for fit indexes in covariance structure analysis: Conventional criteria versus new alternatives. Struct. Eq. Model. Multidiscip. J. 1999, 6, 1-55. [CrossRef]

156. Dawson, J.F. Moderation in management research: What, why, when, and how. J. Bus. Psychol. 2014, 29, 1-19. [CrossRef]

157. Darcy, C.; Hill, J.; McCabe, T.; McGovern, P. A consideration of organisational sustainability in the SME context: A resource-based view and composite model. Eur. J. Train. Dev. 2014, 38, 398-414. [CrossRef]

158. Vicente, M.; Abrantes, J.L.; Teixeira, M.S. Measuring innovation capability in exporting firms: The INNOVSCALE. Int. Market. Rev. 2015, 32, 29-51. [CrossRef] 
159. Racela, O.C. Customer orientation, innovation competencies, and firm performance: A proposed conceptual model. Procedia-Soc. Behav. Sci. 2014, 148, 16-23. [CrossRef]

160. Yang, C.-C.; Marlow, P.B.; Lu, C.-S. Assessing resources, logistics service capabilities, innovation capabilities and the performance of container shipping services in Taiwan. Int. J. Prod. Econ. 2009, 122, 4-20. [CrossRef]

161. Lai, W.-H.; Lin, C.-C.; Wang, T.-C. Exploring the interoperability of innovation capability and corporate sustainability. J. Bus. Res. 2015, 68, 867-871. [CrossRef]

162. Wijethilake, C.; Ekanayake, A. Proactive Strategic Responses to Corporate Sustainability Pressures: A Sustainability Control System Framework. In Advances in Management Accounting; Emerald Publishing Limited: Bingley, UK, 2018; pp. 129-173.

163. Wijethilake, C.; Lama, T. Sustainability core values and sustainability risk management: Moderating effects of top management commitment and stakeholder pressure. Bus. Strategy Environ. 2019, 28, 143-154. [CrossRef]

164. Aziz, N.A.A.; Manab, N.A.; Othman, S.N. Exploring the perspectives of corporate governance and theories on sustainability risk management (SRM). Asian Econ. Financ. Rev. 2015, 5, 1148. [CrossRef]

165. Ali, F.; Kim, W.G. A comparative study of CB-SEM and PLS-SEM for theory development in hospitality research. In Proceedings of the 3rd World Research Summit for Tourism and Hospitality, Orlando, FL, USA, 13-16 December 2019.

166. Hair, J.F., Jr.; Sarstedt, M.; Ringle, C.M.; Gudergan, S.P. Advanced Issues in Partial Least Squares Structural Equation Modeling; Sage Publications: Thousand Oaks, CA, USA, 2017.

167. Chin, W.W.; Peterson, R.A.; Brown, S.P. Structural equation modeling in marketing: Some practical reminders. J. Market. Theory Pract. 2008, 16, 287-298. [CrossRef]

168. Henseler, J.; Ringle, C.M.; Sarstedt, M. A new criterion for assessing discriminant validity in variance-based structural equation modeling. J. Acad. Market. Sci. 2015, 43, 115-135. [CrossRef]

169. Fornell, C.; Larcker, D.F. Structural equation models with unobservable variables and measurement error: Algebra and statistics. Erratum 1981. [CrossRef]

170. Voorhees, C.M.; Brady, M.K.; Calantone, R.; Ramirez, E. Discriminant validity testing in marketing: An analysis, causes for concern, and proposed remedies. J. Acad. Market. Sci. 2016, 44, 119-134. [CrossRef]

171. Inci, A.C.; Narayanan, M.; Seyhun, H.N. Gender differences in executives' access to information. J. Financ. Quant. Anal. 2017, 52, 991-1016. [CrossRef]

(C) 2019 by the authors. Licensee MDPI, Basel, Switzerland. This article is an open access article distributed under the terms and conditions of the Creative Commons Attribution (CC BY) license (http://creativecommons.org/licenses/by/4.0/). 